\title{
Implementation of Virtual Reality for Virtual Laboratories on Plant Anatomy Lessons
}

\author{
Muhammad Adi Khairul Anshary ${ }^{1}$, Ryan Ardiansyah ${ }^{2}$, Ringgit Al-Gifari ${ }^{3}$ \\ \{adikhairul@unsil.ac.id¹, ryanardiansyah@unsil.ac.id², ringgitalgifari23@gmail.com \} \\ Department of Informatics, Faculty of Enginnering 1,3, \\ Depatment of Biology Education, Faculty of Teacher Training and Education ${ }^{2}$ \\ Universitas Siliwangi Tasikmalaya
}

\begin{abstract}
Plant anatomy is a course that requires students to be able to observe cell characteristic in qualitative and quantitative. Qualitative observation is understanding the characteristics of cells in terms of features, shapes, function, and located in organs. While quantitative observation is understanding the characteristic of cells in terms of size and modeling in 3 dimensions. All this skills can be a burden for students in learning process takes conventionally (face to face and ordinary practicum). So, it need a new learning media for students in Virtual Reality (VR). This study aims to build a virtual lab application to help students understanding plant anatomy by using VR media. VR allows students to learn in new ways. VR will bring students into virtual world but feel like real world. This VR application consist of several parts, there are pretest, tutorial, simulation, and posttest. Based on trial phase which is calculated by t-test and $\mathrm{N}$-gain score (\%) shows that there is effectiveness in using VR Virtual laboratory can make students to carry out lab work without being bound by time and place. In addition, students will also get more clear and interactive description of plant anatomy in qualitative and quantitative observation.
\end{abstract}

Keywords: virtual reality, virtual laboratory, plant, anatomy.

\section{Introduction}

Plant anatomy courses are one of the subjects that tend to be qualitative and are considered not to be developed in the direction of quantitative efficacy[1]. However, this course begins to lead to mathematical modeling where students are required to be able to draw three dimensions (3D) by combining two-dimensional (2D) images of two transverse and longitudinal incisions observed using a microscope.

Based on preliminary observation data, that there are still many students who do not understand the 3D form of a cell if only using photos from a microscope. This happens because not all photos are produced from a good incision. As a result students can only imagine roughly how the 3D shape of a cell from the observation of two different incisions. This is what causes students to eliminate the characteristics of a cell as a whole, for example, assume that all cell sizes are the same. This is because awareness about the scale of students is still low. In addition, it was also found that there were other obstacles, namely the number of errors experienced by students in describing the $3 \mathrm{D}$ shape of a cell resulting from a combination of two $2 \mathrm{D}$ images. So, learning media are needed to support the process [2]. 
The learning process of plant anatomy requires different media. The media can take the form of an attractive computer application by implementing Virtual Reality (VR) to present virtual laboratories that can display objects that resemble the original. Virtual reality is a technology that allows users to interact with virtual environments that are simulated by computers, so users feel they are in the real environment [3]. Virtual reality can be applied to various fields, including learning and teaching and learning processes both in schools and in universities [4].

Virtual Reality is very suitable to be applied in the field of Education and training [5]. By applying VR technology, students can experience a variety of scenarios, including scenarios that are physically impossible to install in the classroom. There are several studies that have implemented virtual reality technology, including: virtual reality is used to assess, study and treat mental health disorders [6]. In addition, VR is used as an educational and training tool in the medical field [7]. Other research shows that VR is applied in human anatomy education [8], English language learning for tourists [9], and learning and training for prospective nurses [10].

This technology is a new breakthrough in teaching and learning activities, because by utilizing this technology can increase the imagination of students to design and describe a cell into 3D form precisely by presenting cell objects directly with a complete scale description. Thus teaching and learning activities in plant anatomy courses will be more interesting, easy, and fun.

\section{Research Methodology}

Virtual reality application is a development of multimedia applications. This application involves a lot of media consisting of text, images, audio and animation. In developing this multimedia application, Luther-Sutopo's multimedia application development methodology was used.

According to Luther [5], the multimedia application development methodology is divided into 6 stages, namely concept (design), design (designing), collecting materials (material collection), assembly (manufacture), testing (testing) and distribution (distribution). These six stages in practice do not have to be done sequentially, these stages can exchange positions. However, the concept stage must be the first step taken.

Below are the stages of application development carried out by following the stages of Luther-Sutopo:

1. Concept

The initial stage of application development is to determine the concept. The purpose of developing this plant anatomy learning application is to help students understand the learning material of plant anatomy courses. Thus the target users of this application are students between the ages of 17 and 20 years. In this course, there is a lot of modeling of plant parts in the form of images, therefore this application must be able to display images of plant parts clearly and correctly so that students get a clear picture of the parts of the plant. 


\section{Design}

The next stage is designing the style, appearance, material requirements of the application using storyboards. The flow of the application to be made is adjusted to the practicum of plant anatomy. Each stage of the lab is simulated in a scene. Thus in this application several scenes are designed as follows:

Table 1. Storyboard

\begin{tabular}{cl}
\hline Scene & \multicolumn{1}{c}{ Display } \\
\hline 1 & User Manual of Application \\
& Plant Anatomy Practicum: \\
& 1. Take a pipette \\
& 2. Take safranin using a pipette \\
& 3. Prepare glass \\
& 4. Drip safranin into the glass \\
& 5. Take a razor blade \\
& 6. cutting the stem transverse / longitudinal \\
& 8. Store glass on the microscope. \\
3 & See the results of the incision on the microscope
\end{tabular}

3. Material Collecting

The next stage is to prepare materials related to the application. The materials prepared are in the form of laboratory room displays, lab tools and materials such as glass, pipettes, microscopes, safranin water, razor blades and plants.

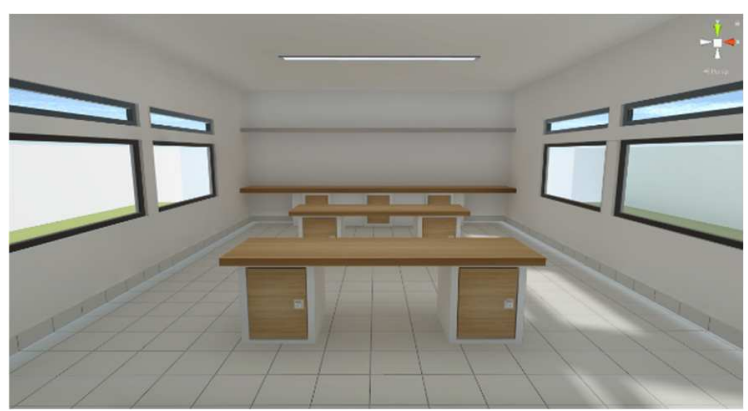

Figure 1. laboratory space 

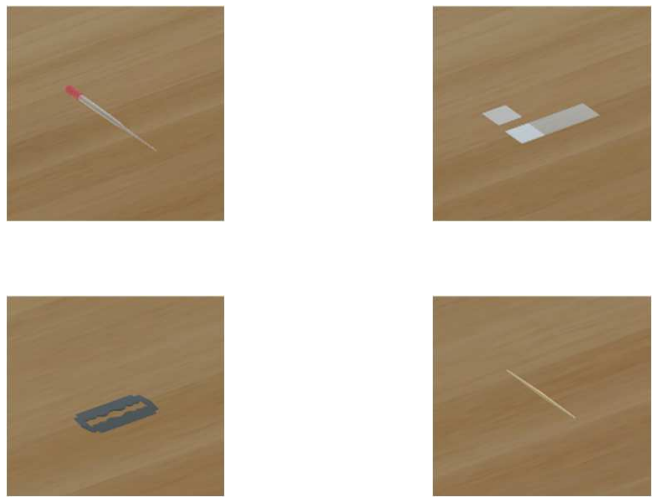

Figure 2. laboratory tools
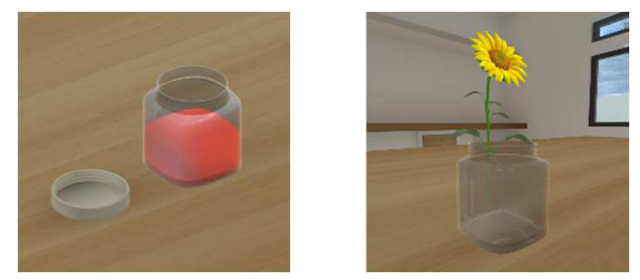

Figure 3. laboratory materials
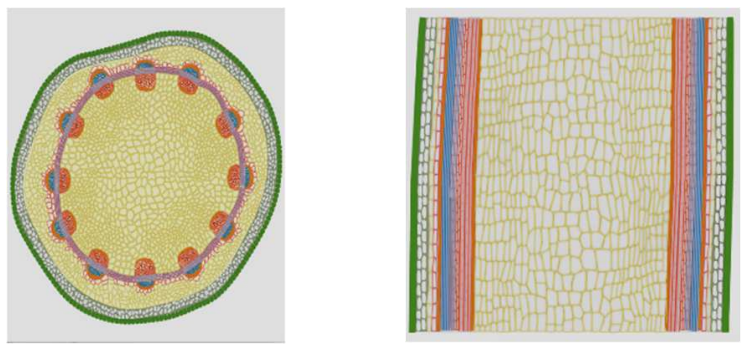

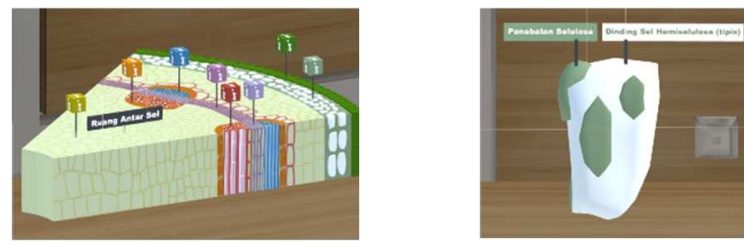

Figure 4. The results of the incision are seen in the microscope

\section{Assembly}

At the assembly stage, all the material that has been prepared is combined and assembled into a complete application with regard to the storyboard that has been made.

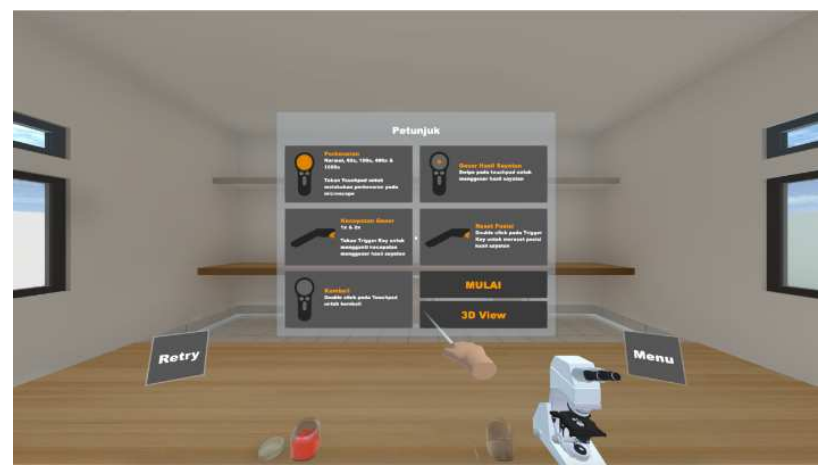

Figure 5. Scene of User Manual

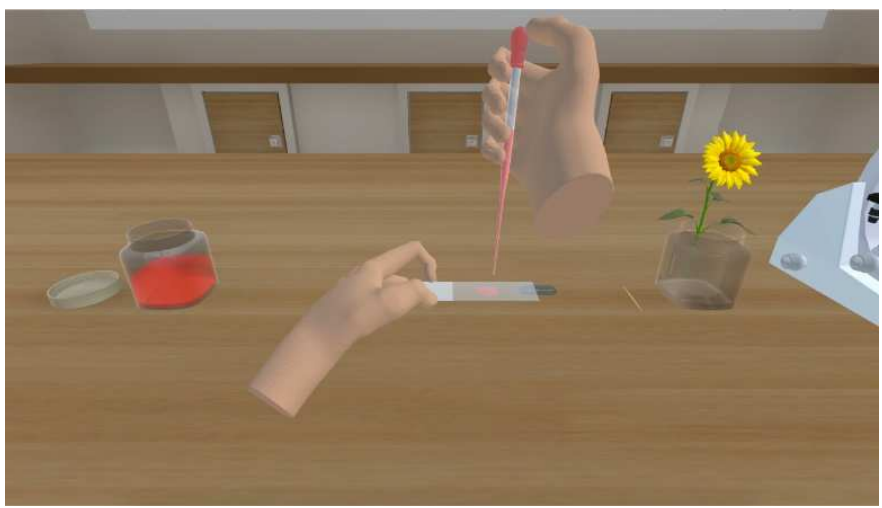

Figure 6. Scene when dripping safranin liquid on top of glass 


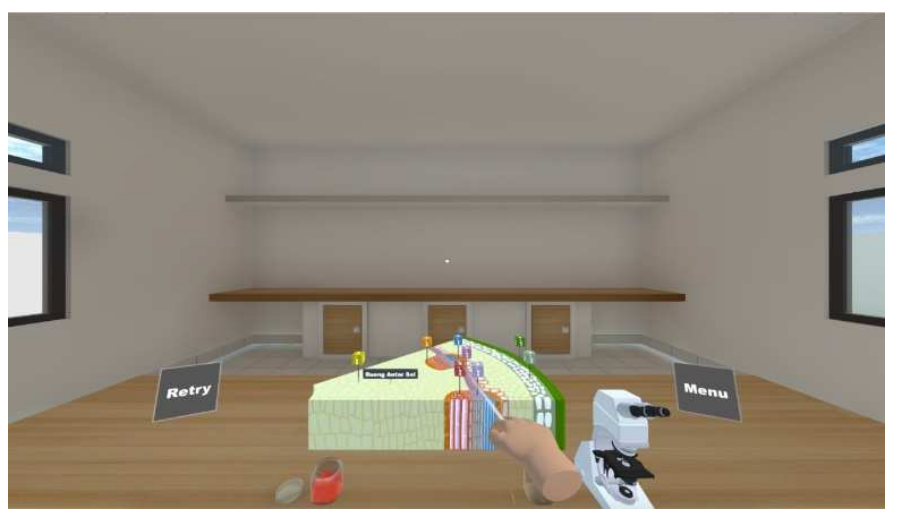

Figure 7. Scene when viewing the results of the incision in 3D in the Microscope

5. Testing

Before the application is used, it must be tested first to determine the level of readiness and conformity with the purpose of previous development. This application testing is done in three stages. The first step is to test each functional of all elements in the application. The results of testing from this stage are all functions of the application running according to the original plan.

The second step is to test the usefulness of this application to end user samples. The aim is to find out the effective use of this application in increasing understanding of the course of Plant Anatomy. This stage of testing involves 13 biology education students and is done by giving a pre-test and post-test.

The third stage is implementing the User Acceptance Test. The aim is to find out the level of the end user regarding the ease and usefulness felt by the user. In this testing the tester filled out the questionnaire provided.

6. Distribution

The last stage of developing this application is to distribute this application until it can be used by the last user. This application is distributed by being formed in the apk format so that it is easily installed on a mobile device that has an Android operating system.

\section{Result and Discussion}

This study aims to implement Virtual Reality technology on learning media so that it can assist students in studying plant anatomy. The implementation of Virtual Reality in learning plant anatomy is new. Previously, learning was only done conventionally by practicing in a laboratory. By using this technology, students can better understand this learning related. Therefore, it is necessary to test the effect of using this application on students understanding of plant anatomy lessons. Testing was carried out in several stages. The first test was conducted to test the truth of the material presented in the application, namely plant anatomy. The test was conducted by conducting interviews with experts who were represented by a lecturer in plant anatomy. The results of this test states that the material presented in this application is in accordance with what is the theory of plant anatomy. The second test was conducted to 
determine the feasibility of using the application. This test is done through the User acceptance test. The results of these tests indicate that the application is already meeting the needs of the user as the end users. The final test was conducted on students to determine the quality and influence of this application on the user's understanding of plant anatomy material. Testing is done by comparing the results of the pre-test and post-test conducted to 13 students. The results of this comparison will show the effectiveness of the application being built.

Table 2. Paired samples Test

\begin{tabular}{|c|c|c|c|c|c|c|c|c|}
\hline \multirow[b]{4}{*}{$\begin{array}{c}\text { Pair } 1 \\
\text { pretest - } \\
\text { postest }\end{array}$} & \multicolumn{5}{|c|}{ Paired differences } & \multirow{3}{*}{$\mathrm{t}$} & \multirow{3}{*}{$\begin{array}{l}\mathrm{D} \\
\mathrm{f}\end{array}$} & \multirow{3}{*}{$\begin{array}{c}\text { Sig } \\
(2- \\
\text { tailed) }\end{array}$} \\
\hline & \multirow{3}{*}{$\begin{array}{c}\text { Mean } \\
-13.077\end{array}$} & \multirow{2}{*}{$\begin{array}{c}\text { Std. } \\
\text { dev. } \\
11,996\end{array}$} & \multirow{3}{*}{$\begin{array}{l}\text { Std.error } \\
\text { mean } \\
3,327\end{array}$} & \multicolumn{2}{|c|}{$\begin{array}{l}95 \% \text { conf interval } \\
\text { of the diff }\end{array}$} & & & \\
\hline & & & & $\begin{array}{l}\text { Lower } \\
-20326\end{array}$ & $\begin{array}{l}\text { Upper } \\
-5828\end{array}$ & & & \\
\hline & & טקנים 11 & & & & טנ, & 12 & 0,02 \\
\hline
\end{tabular}

Based on table 2 above, the sig value is known. (2-tailed) is $0,002<0,05$, and t count 3,930 $>$ $\mathrm{t}$ table 2,179 , then $\mathrm{H} 0$ is rejected and $\mathrm{Ha}$ is accepted, so it can be concluded that there are differences in the average between the pretest and posttest learning outcomes which means there is an influence of media use VR in improving student learning achievement in Plant Anatomy.

To see the effectiveness, $\mathrm{N}$-gain score (\%) is calculated. The $\mathrm{N}$-gain value obtained is $76.45 \%$ included in the effective category so that it can be concluded that the use of VR media is effective to improve learning achievement in Plant Anatomy.

\section{Conclusion}

The conclusion obtained from the results of the research that has been done is that it has been successfully created a new learning tool for plant anatomy courses by applying Virtual Reality technology. The use of this learning media can improve the learning effectiveness of plant anatomy as evidenced through sampling tests for students conducted by testing the understanding before and after using this application.

For the next study it is recommended to add the VR media specifications that are used so that it can respond to hand movements forward and backward. while the application that is generated at this time can respond to hand movements up, down, to the right side and to the left side.

\section{Acknowledgments.}

We would like to Thank to Direktorat Riset dan Pengabdian kepada Masyarakat (the Directorate of Research and Community Service) (DRPM) of the Ministry of Research, Technology and Higher Education for funding this research through the "Penelitian Dosen Pemula" scheme in 2018. Our thanks also go to LP2M-PMP Universitas Siliwangi for helping this research process to completion. 


\section{References}

[1] R. Andriansyah, "PENGEMBANGAN BAHAN AJAR ANATOMI TUMBUHAN UNTUK MENUNJANG LITERASI KUANTITATIF MAHASISWA BIOLOGI.” 2014.

[2] Y. Efendi, T. H., and E. Khoirunnisa, "Penerapan Teknologi AR (Augmented Reality) pada Pembelajaran Energi Angin Kelas IV SD di Rumah Pintar Al-Barokah,” Stud. Inform. J. Sist. Inf., vol. 9, no. 1, pp. 29-47, 2016.

[3] G. Kim, Designing Virtual Reality Systems. 2005.

[4] R. Puspita and M. Yamin, "Sistem Informasi Aplikasi Virtual Lab," Proceeding, Semin. Ilm. Nas. Komput. dan Sist. Intelijen (KOMMIT 2008), no. Kommit, pp. 190-198, 2008.

[5] C. Christou, "Virtual reality in education," Affect. Interact. Cogn. Methods E-Learning Des. Creat. an Optim. Educ. Exp., no. June 2010, pp. 228-243, 2010.

[6] J. Of, C. Reports, and S. Saraf, "This is an Open Access article distributed under the terms of the Creative Commons Attribution License (creativecommons.org/licenses/by/3.0)," vol. 3, no. 1, pp. 92-95, 2013.

[7] F. J. J. M. G. E. M. J. S. L. et al Santiago González Izard; Juanes, Juan A; García Peñalvo, . "Journal of Medical Systems; New York," vol. 42, no. 3, 2018.

[8] P. R. Izard, Santiago González; Juanes Méndez, Juan A; Palomera, "Journal of Medical Systems; New York," vol. 41, no. 5, 2017.

[9] B. W. Lee, H. Y. Shih, Y. T. Chou, and Y. S. Chen, "Educational Virtual Reality implementation on English for Tourism Purpose using knowledge-based engineering," in Proceedings of the 2017 IEEE International Conference on Applied System Innovation: Applied System Innovation for Modern Technology, ICASI 2017, 2017, pp. 792-795.

[10] J. Elliman, M. Loizou, and F. Loizides, "Virtual reality simulation training for student nurse education," 2016 8th Int. Conf. Games Virtual Worlds Serious Appl. VS-Games 2016, no. October 2017, pp. 13-15, 2016. 